UDC 821.521-31.09 Šusaku E.

https://doi.org/10.18485/ms_zmskij.2020.68.1.7

Др Далибор Д. Кличковић

\title{
ИНКУЛТУРАЦИЈА ИЛИ ТРАНСФОРМАЦИЈА: ХРИШЋАНСТВО У РОМАНУ ТИШИНА ЈАПАНСКОГ ПИСЦА ЕНДО ШУСАКУА
}

Ендо Шусаку (1923-1996) назива се често највећим „католичким писцем“ Јапана. Најзначајнији део његовог обимног опуса посвећен је, доиста, управо суочавањима с властитом католичком вером. Примивши крштење мајчином вољом, он брзо налази да је та страна наука о спасењу у нескладу с његовим јапанским сензибилитетом. Из те спознаје напајаће се сва његова настојања да у својој књижевности артикулише другачије разумевање хришћанства. У роману Ћуйање он долази до личности страдалног Христа, као тужног сапутника немоћних на путу страдања. Чини се, међутим, да такав Христос бива ослабљен на начин да губи део својих божанских прерогатива, остајући протумачен у претежно антропоцентричној перспективи. Због тога се Ендоова верзија хришћанства, у јапанском контексту, боље уклапа у оквире модернизоване будистичке него традиционалне хришћанске сотериологије. Но, реч је уједно и о адаптацији хришћанског учења која је модерног и хуманистичког карактера, чак и више него особено оријенталног. Ендоова „теологија“ делатна је као модел дијалога у односу с Богом у оквирима књижевног дела. Као модел стварног односа према трансценденцији, међутим, она припада типу „слабе вере“, којом се не обавезује ниједна страна у тој заједници - ни Христос ни човек.

Кључне речи: јапанска књижевност, Ћутање, Ендо Шусаку, хришћанство, инкултурација, религија.

У овоме тексту, размотрићемо још једном тему која већ деценијама заокупља пажњу проучавалаца и читалаца послератне књижевности Јапана. Вишеструки су мотиви, а они су често наговештавани током излагања што следи, који су нас навели на то да се изнова окренемо предмету који данас нипошто није нов и неистражен. Непрестано надахњује и нову актуелност стиче судбина хришћанства у Јапану, чија званична историја почиње 
још средином XVI века, да би, након почетних мисионарских успеха, од половине следећег столећа била прекинута суровим прогонима и угушена у крви мученика. Хришћанство је, међутим, наставило да живи и након тога, међу тзв. скривеним хришћанима (隠れキリシタン/kakure kirishitan $)^{1}$ према којима је Ендо Шусаку (遠藤周作, 1923-1996), по многима најзначајнији „католички писац“ Јапана, ${ }^{2}$ гајио посебан однос солидарности и разумевања. У таквом амбивалентном, и једино могућем, постојању јапанских хришћана од XVII века, Ендо открива завичајно место своје хришћанске вере, као и корене својих колебања и дилема.

Књижевни и духовни споменик промишљања усуда који је задесио хришћанство у његовој земљи, али и пре и више од тога - сведочанство о личном суочавању с хришћанском вером, јесте роман Ћуйање (沈㷛/ Chinmoku, 1966). Пишчев стваралачки опус, и пре и после овог романа, необично је обиман и у значајној мери сачињен од дела која се баве управо питањем прихватања хришћанства у Јапану. И не само у Јапану, већ и у самоме писцу, који, у време када се у свету мења неповољна перцепција земље из ратног раздобља и када наступа доба нове афирмације јапанске духовне културе, ${ }^{3}$ лично искуство вере и хришћанство као универзални пут спасења покушава да протумачи из перспективе човека Истока и тако их уподоби домаћем сензибилитету.

Већ први Ендоов есеј Богоови и Бог̄ (神々と神と/Kamigami to kami to, 1947) наговештава доживотно „рвање“ с хришћанством којем, како је често истицао, не прилази сопственом вољом већ крштењем по вољи мајке, и саме крштене у тренутку озбиљне животне кризе. Тешко је са сигурношћу казати који су то рани формативни утицаји обликовали „изворно јапански“ духовни пејсаж код Ендоа, но у време настанка романа Ћуйање већ су и на ширем светском плану увелико делатни утицајни дискурси о посебностима јапанске културе. Они су се кроз јапанску историју често јављали као националистички рефлекс, у временима кад ојачају интернационалне и космополитске тежње и вредности у друштву (SWYNGEDOUw 1976). ${ }^{4}$ Ваља имати на уму и важну чињеницу да такве теорије о јапанској јединствености, које су увек нужно конотирале и одређену супериорност јапанске културе у неколиким

\footnotetext{
${ }^{1}$ Овај појам односи се данас на оне јапанске хришћане који се нису вратили Католичкој цркви по укидању забране у XIX веку, већ су задржали своју особену праксу насталу у столећима изолације.

2 Често се може чути да се Ендо назива ,јапанским Грејемом Грином“.

3 Године 1968. јапански писац Кавабата Јасунари прима Нобелову награду за књижевност. У своме говору том приликом, Кавабата не помиње скорашњу ратну прошлост Јапана, већ открива порекло своје књижевности у естетици средњовековних будистичких монаха и песника.

${ }^{4}$ Како овај аутор истиче, шездесетих година почиње управо нови талас јачања националне свести, што је зацело охрабрило Ендоову решеност у трагању за ,јапанским хришћанством“. Ова намера корени се у отуђујућем и тескобном сусрету с хришћанском културом Запада током студијског боравка у Француској.
} 
њеним сегментима, нису потицале увек и искључиво из Јапана, већ су их у послератним деценијама потхрањивале и студије западних аутора и ентузијаста.

У пишчевом случају, дакле, можемо идентификовати два изворишта архетипова који су обликовали његов духовни профил: хришћанство, примљено посредством мајке која ће остати оличење хришћанских врлина и недостижан идеал - печат мајчинске љубави утиснуће и у лик Христа; широка неиздиференцирана основа домаће духовности настала у вековима интеракције и синкретистичког прожимања страног будизма и домаћег шинтоизма. Ендо ће ову традиционалну спиритуалност још у есеју Бог̄oви и Бог̄ прилично слободно одредити као пантеистичку, поистовећујући анимистички политеизам шинтоизма и пантеизам будистичког порекла. Он не осећа потребу да такво своје наслеђе доследно и систематски објасни, због чега, за разлику од Кавабатиног случаја, остајемо ускраћени за прецизнија сазнања о томе с којих се то тачно традиционалних извора напајао његов , јапански сензибилитет“. Претпостављамо, стога, да је пишчев главни оријентир ипак остајало хришћанство, које ће реинтерпретирати према својој широко постављеној „источњачкој“ матрици. У томе су му, вероватно, помогли тада актуелни модели реафирмације јапанске културе, настали углавном модернизацијом естетских и спиритуалних идеала јапанскога средњег века. Културолошки и духовно засићени познатим и блиским елементима традиције, ови обрасци мотивисали су Ендоову потребу да хришћанство прилагоди тако претпостављеним антрополошким предиспозицијама јапанског човека.

Када се у мисиологији Католичке цркве у обзир узимају специфичности културе која је циљ евангелизације, онда говоримо о инкулӣурацији. Морамо, међутим, овом приликом да искажемо противљење свођењу Ендоовог односа с хришћанством на некомпатибилност поларизованих духовних парадигми, Истока и Запада, одакле, наводно, и потреба за таквим прилагођавањем. Као што ћемо казати у наставку, корен пишчевих недоумица и немира у погледу вере проналази се обично у културолошкој неподударности парадигми мишљења, чиме се, сматрамо, олако превиђа озбиљан проблем могућности веровања уопште, у тада већ постмодерном добу. Поједностављивању тог тешког питања на стереотип о разликама међу културама допринео је, додуше, и сам писац. У наше време, а по свој прилици и одувек, сваки сусрет народаิ - но ништа мање и сваки лични сусрет - с хришћанством, међутим, мора бити већ својеврсна инкултурација. У овоме такође, верујемо, леже значај и актуелност ове теме и код нас, будуће да се не исцрпљује само у својој јапанолошкој димензији.

Међу нашим савременим писцима, о свом сазревању у византијско-православном наслеђу у Жичкој исйовестии казује, на пример, Иван Негришорац. Иако његово песничко дело још увек нисмо добро упознали, Жичком исйовещћ простора пустињачким испосницама и духом исихазма, врхунац којег процеса 
је био сусрет с Петром Коришким и Лестивицом чувеног игумана синајског. Данашњи боготражитељ на нашем простору не говори, дакле, о инкултурацији хришћанства, већ о безусловној предаји свог паганског света просветљујућој истини - хришћанство се ту, а не њему претходећа веровања, признаје као родно место и завичај душе. Но, у њеном најличнијем кутку, и не без многих ломова, неминовно ће доћи до сасвим особеног сусретања с Христом, и то на свакој индивидуи једини могућ начин. Таквој ће се души, у мери њеног смирења, прилагођавати и вечито кенотички Христос, а природа њихове везе остаће тајна за све. Отуда су ваљда и највећу пажњу одувек привлачили они оци Цркве код којих се осећају снажна индивидуалност и аутентичност, па чак и извесна смелост, њиховог искуства и доживљаја општих догмата. У том смислу кажемо да одувек, а у данашње време и више него пре, сваки сусрет с хришћанством неминовно већ јесте одређени вид инкултурације.

И само то „православно-византијско“, с друге стране, плод је развоја хришћанства у хеленскоме делу Римског царства. Исихазам у XIV веку сажима векове свог дотадашњег имплицитног постојања и постаје највиши израз духовних тежњи претходног миленијума, непосредно пре надолазеће хуманистичке револуције Ренесансе (МАЈЕндоРФ 2012). И док ће многи данас исповедити управо веру у тако схваћену хришћанску духовност, исихазам ће за већину савремених хришћана значити озбиљан изазов, који захтева интензиван дијалог с дубоком прошлошћу и битно другачијим претпоставкама старих култура. Национална припадност српској баштини по себи неће нужно значити и предност у оживљавању древних образаца и закона духовног живота. За хришћане најранијих времена вера није ни била питање некаквог личног или романтичарски схваћеног националног идентитета, нити се остваривала, као што је то данас случај, превасходно у дубинама приватне субјективности, већ у малој евхаристијској заједници верујућих и у простој али обавезујућој форми - и у ишчекивању другог Христовог доласка. У вековима од Константинове ере, пак, припадност хришћанској вери подразумевала се у целом друштву, стичући у позној Византији и националну хеленистичку самосвест. Тек у време секуларизације друштава Запада и развоја модерне индивидуалности питање вере прешло је у домен приватног, личног опредељења сваког члана гррађанског̄ друштва. ${ }^{5}$ Право је питање, међутим, управо то какво може бити такво „лично хришћанство, будући да је вера раних, па и оних каснијих, хришћана модерном човеку, не само Јапана већ подједнако и Запада, већ увелико недоступна.

${ }^{5}$ Након што је 1873. године укинута забрана хришћанства, слобода вероисповести у Јапану прописана је Уставом Јапанске царевине (чл. 28, 1890), у којем се каже следеће: „Уколико се тиме не ремете мир и поредак, нити се нарушавају дужности грађана као царских поданика, свако поседује слободу вероисповести“. Примећује се да су грађани за царски устав још увек поданици а слобода вероисповести постојала је у мери која је веома зависила од тумачења извршилаца уставних права и обавеза. И поред тог ограничења, појединац се по први пут у историји Јапана могао слободно изјаснити као хришћанин. 
Архимандрит Софроније Сахаров изразио је сумње по питању тога у којој је мери данашњи човек, без обзира на порекло, доиста у стању да усвоји етичке и сотериолошко-метафизичке претпоставке хришћанства. Иако се данашњи свет назива постхришћанским, примећује он, хришћанство у својим правим димензијама никада није ни било шире прихваћено на европском простору (САХАРОВ 2009:64). Утврђивање духовног раста модерне индивидуе, дакако, ни издалека није циљ нашег излагања, но неопходним сматрамо нагласити то да се питање могуућностии хришћанске вере у наше време не може просто сагледавати као проблем различитости култура на синхронијском плану њихових статичних идентитета, што се управо чини у већини покушаја да се расветли природа Ендоове рецепције католичанства. Увек је религија, па тако и хришћанство, обремењена историчношћу, те проткана многим и не увек хомогенизованим слојевима, због чега је сваки религиозни етос данас нужно осетљив на скептично и релативизујуће мишљење. И Ендо је, као модерни писац већ увелико модернизованог̄ и секуларног Јапана, у своме односу према трансцендентној реалности морао бити снажно условљен тековинама хуманизма и рационализма, што се олако занемарује. Дубљи, архајски талози веровања предака, с којима се он доводи у везу, њему нису могли бити непосредно доступни, те је и наводни пишчев повратак „коренима“ у великој мери био део модернистичког процеса откривања традиције као њеног стварања. ${ }^{6}$

Ово значи, другим речима, то да између писца и његове хришћанске вере не стоји толико древна јапанска духовност, како то у својој веома запаженој и вредној студији доказује Еми Масе-Хасегава (MASE-HASEGAWA 2008), колико, заправо, рационалност модерне индивидуе, која човеку Ендоовог друштвеног и интелектуалног профила више не дозвољава простосрдачну веру. Не смемо неопрезно претпоставити, дакле, то да су писцу на располагању непосредно били стратуми старије „домаће“ религиозне свести и тако занемарити снагу секуларизације, која је до тада, у јавном и интелектуалном простору Јапана, већ неутрализовала раније спиритуалне парадигме и дискурсе. ${ }^{7}$ Хасегава, и сама хришћанка, опредељује се ипак за контрастивни модел интерпретације Ендоове дилеме као сукоба двају делатних схватања апсолутног Бића, супротстављајући западњачки модел, који полази од строгог очинског ауторитета једнога Бога на обавезујући начин описаног у појмовима рационалне теологије и, с друге стране, источњачког, мајчински самилосног и плуралног по карактеру својих религијских образаца.

Суочавамо се, дакле, с једном основном и простом запитаношћу: у којој је мери Ендоова потреба да у својој књижевности осмисли лик „транскул-

${ }^{6}$ O историјској динамици у религијама Јапана в. SUEKI 2016.

${ }^{7}$ Масе-Хасегава као референтни оквир тумачења Ендоове теологије одређује тзв. кощинт̄и, тј. древни шинтоизам. Иако овај термин указује на првобитни облик домаће религије, пре доласка будизма, реч је о систему веровања који је конструисан последњих векова у оквиру школа националне идеологије (伊藤 2014). 
туралног“ Христа и тако га помири с менталитетом човека Јапана заиста условљена пишчевим источњачким идентитетом, а у којој је, пак, израз личне немогућности да прихвати основне догме хришћанске вере у оквирима традиционалне теологије. У прилог тези о извесној културолошкој страности хришћанства на јапанском тлу говори, додуше, целокупна историја његове рецепције у тој земљи. Ућимура Канзо (1861-1930), једна од најзначајнијих личности протестантског хришћанства у Јапану XIX века, каже следеће: „Која би од деветнаест различитих хришћанских деноминација данас ангажованих у евангелизацији Јапана могла стећи најснажније упориште? По нашем мишљењу (...), ниједна од њих. Један од разлога јесте у томе што је просто пресађивање било чега егзотичнога на јапанском тлу до сада непознато. Било да је у питању каква политичка, научна или друштвена материја, неопходно је да буде увелико измењена рукама самих Јапанаца пре него уопште буде могла да опстане у јапанском поднебљу“ (MuLlins 1998:35-36). И заиста, чак и такви непоколебљиви хришћани као што су Ућимура или његов савременик Ебина Данђо, примили су хришћанство на начин који није био у сукобу с њиховим конфуцијанским светоназором и самурајским кодексом (бущиидо), хармонизујући га чак и с политеистичким шинтоизмом.

Јапански хришћани модерног доба брзо су закључили да је мисионарско хришћанство оптерећено многим културолошким елементима и искључиво у одбацивању јапанских видова религиозности. Они најрадикалнији и најревноснији међу њима, као што је Ућимура, нису оклевали у томе да стране елементе уклоне а хришћанство је морало бити спремно на компромис с основним законом рецепције страних религија у тој земљи: ниједно учење, укључујући и домаћи шинтоизам, није могло бити апсолутно у мери и на начин да искључује хетерогене религиозне праксе. ${ }^{8}$ Сваки од великих система веровања и мисли на тлу Јапана имао је своју друштвену и духовну улогу - и потребу за другачијим формама религиозности с којима је остваривао симбиотички однос међусобне комплементарности.

У Ендоовом случају, међутим, није у питању било, у Јапану доминантно, протестантско хришћанство, прилагодљиво духу револуционарног периода Меиђи (1868-1912), већ католичанство које се није дало извести из храма, као што је то учинио протестант Ућимура оснивајући хришћански покрет без институционализоване цркве (無教会主義/mukyokaishugi, тj. бесцрквеност), нити је могло, будући светотајинско по свом пореклу, постојати

\footnotetext{
8 Разговори с верујућим људима у Јапану потврђују нам управо чињеницу да је њихова верска свест суштински плуралистична. Заједничко језгро међу различитим веровањима чине етичка свест, однос према природи и начелни консензус о реалитету духовног света, док догматска садржина учења није од пресудног значаја, колико је то његова способност да уређује однос личног микрокосмоса и макроплана егзистенције. Тај макроплан није примарно метафизички већ се остварује као човеково друштвено постојање, односно као његова добробит на овом свету (тзв. 現世利益/genze riyaku).
} 
ван литургијског и обредног живота. Такво ће хришћанство, примљено без учешћа сопствене воље, Ендо поредити с неприкладним прешироким оделом. Ово поређење повезује Ендоа с још једном важном личношћу у савременој историји Католичке цркве у Јапану, с особом која је добро разумела ову пишчеву дилему.

Иноуе Јођи (1927-2014), католички свештеник и доживотни Ендоов пријатељ, први је у контексту јапанског хришћанства употребио поређење стране вере с оделом неодговарајућег кроја. Њихово познанство потиче из времена када су истим бродом, 1950. године, путовали у Француску, као путници „ниже класе“, и на начин који је симболизовао тадашњи положај Јапана у свету: путовали су, по сведочењу самог писца, као прави представници једног пораженог народа - смештени у потпалубљу, у друштву афричких припадника Легије странаца, који су у Јапан допратили јапанске војнике оптужене за ратне злочине у Индокини. Боравак у Француској и на изворима католичанства утицаће слично на обојицу пријатеља, на начин да је у њима пробудио акутну свест о нужности преображаја хришћанства у Јапану, у елементима који су туђи домаћем сензибилитету. Иноуе ће, будући философски креативнији, исходишта јапанске духовности тражити у источњачки схваћеном појму стваралачког нищитавила (無/mu), које је кинески модус концепта йразнине у будизму.

Следећи свој свештенички позив, он тумачи хришћанску теологију у појмовима традиционалне јапанске естетике, али схваћене као актуализација Једнога, тј. онога које је катафатички неодредиво Ништа. Ступајући у заједницу с човеком, по Иноуеу, Бог се јавља као личност, те ту, сматра он, нема никакве противречности - празнина Истока и пуноћа Запада допуњуjу се. ${ }^{9}$ Како то хришћанство „усавршава“ јапанску традиционалну духовност он објашњава на следећи начин: „Онај кога у срце дирне поглед на трешњу у пуном цвату спознао је душу трешње и познаје унутарњу лепоту. Онај ко се, међутим, на томе заустави, тај неће осетити животворни дух Божји, што дише у дубинама тог цвета и живот му даје“" (金子 2016). Већ чињеница да се овде говори о духу који оживотворује биљку а не људско биће, наговештава нам важне далекоисточне теме иманентности животворног начела и стварне природе света који нас окружује, у Иноуеовој мисли. Било да је реч о неоконфуцијанској философији, будистичком учењу или, пак, о теоријама утицајног јапанског нововековног мислиоца Норинага Мотоорија (17301801), човек је дужан да своју, у филофосији Истока, онтолошку истоветност с природом спозна у јединству епистемологије и естетике.

9 Управо у оваквим одважним транскултуралним тумачењима у потрази за једном метарелигијом Иноуе се, а с њим и Ендо, налази на линији нове херменеутике у јапанској религијско-философској мисли, која асимилује страно да би му даровала живот унутар сопствене матрице. Хришћански Бог, дакле, и даље може остати личност, али таква да признаје и друге модалитете изражавања врховне истине. Такав другачији модалитет Иноуе налази у боговима шинтоизма. 
Као хришћанин, Иноуе говори о животворном начелу духа ( $\pi v \varepsilon \tilde{\mu} \mu \alpha)$, које изражава идеограмом са значењем „ветар“(風). Тиме се, по нашем мишљењу, снажно конотира јапански спиритуални контекст, иако идеја о повезаности духа с дахом односно кретањем ваздуха није специфично јапанска. Говорећи о духу, Иноуе, очигледно не без поетског надахнућа, каже следеће: „Док човек живи свој живот, зној живота капље и претвара се у речи.

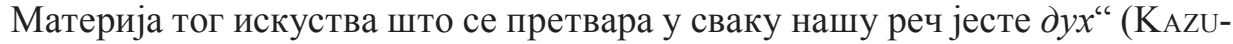
YoSHI 2015:166). У средишту његове теологије, дакле, налази се „дух“, но порекло те „пневмацентричности“, очигледно, није посве хришћанско. Нећемо, у сваком случају, погрешити уколико кажемо да се Иноуе успротивио пре свега рационалистичком и објективизујућем одређивању Божанске личности и настојао је да тајну тројичности Бога искаже имплицитно и у терминима естетике неке врсте, у традиционалном јапанском маниру. Он, додуше, избегава источњачки пантеизам и уобичајено поистовећивање природе с божанством кроз призму будистичког учења о празнини, истрајавајући на суштаствености Божанског духа који обитава у свему и којим све дише. Овакав йанениееизам, међутим, опет је у складу с тежњама Истока да се божанство разуме као иманенција (金子 2016). Треба ипак имати на уму, клонећи се сваког поједностављивања, и то да Иноуе међу неколико личности од највећег утицаја на своју теологију сврстава и Григорија Паламу (1296-1359), који је артикулисао учење о Божанским енергијама.

Чини се да Иноуеова намера ипак лежи у потврђивању конкретне улоге сваке од три ипостаси, које делују у синергији свака с преосталима двема, укључујући у свој живот и целокупну васељену. У овоме се, можда, може препознати и наговештај искуства православне теологије. Ипак, о особеном и источњачки самосвесном промишљању односа Оца и Сина код Иноуеа сведочи његов молитвени „возглас“ $n a m u$ abba (南無アッ八゙), што је и назив за католичку мису коју је он обављао. „Аbbа“ је „ава“ и односи се на Христово обраћање Богу Оцу, док је „пати“ ”еч санскритског порекла која се користи у молитвеној формули буди Амиди, у пракси јапанског будистичког правца Чисте земље, као и другде у јапанском будизму. „Теби се клањам, Оче“каже ова Иноуеова молитва којом он, укључујући и свест о Духу на поменути начин, показује да ипак остаје у оквирима хришћанске теологије, не релативизујући и не умањујући значај било које од три ипостаси.

Ендо Шусаку, с друге стране, није био теолог, а богословске импликације његове интерпретације хришћанства остају у домену имплицитне теологиje. На Иноуеа смо се осврнули јер је својим идејама и избором литературе пресудно утицао на формирање Ендоових погледа. За разлику од философски настројеног Иноуеа, пишчевој визији недостаје мисаона смелост, нити она има снагу проповеди односно било какве практичне литургијске импликације. Оно што, међутим, јесте имала била је неупоредиво снажнија и трајнија рецепција. Не без ироније, дакле, стоји чињеница да је један књижевни дискурс о хришћанству моћније одјекнуо од „професионалног“ богословља које се обраћа појединцу с конкретним позивом да следи Христа, 
не под вођством ауторитета Запада већ у форми према којој би јапански дух био пријемчив и отворен. Иако су многи значајни писци још од првих деценија модернизације земље у XIX веку показали афинитет према хришћанству - међу њима су Китамура Тококу, Шимазаки Тосон, Шига Наоја, Акутагава Рјуносуке и многи други - Ендо је први који је лично и јединствено искуство суочавања с вером преточио у књижевност и посвећено промишљао као свој доживотни задатак.

Пажњу заслужује и његов положај у историји јапанске књижевности управо из угла значаја личног̄ искустива у традицији модерног јапанског романа. Као што се често истиче (WILLIAMS 1999), Ендо припада тзв. трећој генерацији нових писаца (第三の新人/daisan no shinjin) послератног Јапана, који су своју афирмацију стекли почетком педесетих година XX века. Реч је о генерацији писаца стасалих током ратних година, који су, након пораза своје земље, пред собом имали озбиљан задатак да, као интелектуалци и индивидуе, у књижевној форми дају одговоре на тешка питања о свом идентитету и положају у радикално измењеном друштву. Враћајући се традицији јапанског Ја-романа (私小説/shi-shosetsu), они ипак нису више у стању да се повинују монолитном ауторитету сопственога Ја, видљивом раније код неколицине значајних писаца. Дезинтеграција традиционалних вредности, разарање националног самопоуздања и губитак људског достојанства оставили су дубоку празнину на месту где је, још од буђења индивидуалности у раздобљу Меиђи и увек на трагу Запада, бујало снажно осећање сопства. Поједини писци, као што је то Сакагући Анго, пригрлили су ту празнину као одсуство - и чак добровољно лишавање - свега традиционалнога, те тако будистички концепт йразнине постаје, иако у правцу декадентног витализма, егзистенцијални и естетски излаз на згаришту јапанске културе (SHIELDS 2011).

Ендо, као и други писци из поменуте групе у коју га историчари јапанске књижевности сврставају, уводи перспективу подељеног сопства, које осећа присуство другости унутар свог најличнијег простора, на чији је позив дужан да одговори. Постојање такве, од баналног и свакодневнога ,ја“ отуђујуће, инстанце, унело је комплексност и иронију у пишчеву перспективу: сопствено искуство мора бити исприповедано, али увек и поткопано у аутентичности на коју је право себи традиционално присвајало. Другост нижег реда, назовимо је тако, за Ендоа је представљао Запад у ширем смислу, што је готово нужност и за већину других јапанских писаца до његовог времена. Другост вишег реда, пак, на сасвим особен начин за њега представља личност Христа. Да наметнутим крштењем Христос није крочио у његов живот, признаје Ендо, он би одрастао у безбрижну и немарну особу, налик градским беспосличарима и лакрдијашима описаним још у комичним романима старог Токија, које је радо читао. ${ }^{10}$

${ }^{10}$ Говорећи о својим раним годинама, Ендо је помињао своје лоше оцене и бројна неваљалства. Комплекс инфериорности који је из тог периода понео касније ће, у додиру 
Уместо тога, Христос се као Други у ортодоксно католичком лику снажно наметнуо захтевом за светошћу, тј. за освећењем каквоме је тежила и пишчева мајка, у облику несвојственом традиционалној народној религиозности обичних Јапанаца. Након развода, она се са синовима вратила из Манџурије у Јапан и посветила се својој новооткривеној вери. Сећање на њу како се ноћу у својој соби моли с бројаницом у руци, не испуштајући је чак ни током вожње градском железницом, у Ендоа се утиснуло као заповест личног освећења. Неспособност да на ту обавезу одговори, као и на Христов позив на савршеност, Ендо ће сагледавати као издају мајке, и, наравно, издају самога Христа. Издајство мајчине љубави тема је и његовог дела Мајка (母なるもの, 1969). Управо ће, међутим, вера у мајчинско праштање и безусловну љубав која искупљује од сваког греха наћи свој израз у Ендоовој визији Христа, као онога који, искусивши и сам слабост и горчину беспомоћности, опрашта и свима онима који су сувише слаби да понесу тежак крст вере. ${ }^{11}$

Због чињенице да је Ендо у „свом“ Христу као сапутнику немоћних видео једину могућност прихватања међу Јапанцима и једини могући модус опстанка хришћанства на „мочварном“ тлу Јапана, стиче се утисак, не сасвим исправан, да је Ендо некакав источњаки традиционалиста који је реинтерпретирао христологију Католичке цркве по мери духовне антропологије Истока. Нити је, међутим, могуће једнозначно одредити такву источњачку духовност, нити, верујемо, Ендо полази од свестраног промишљања догматске некомпатибилности хришћанства с јапанским религијама. О томе да је у питању била пре свега узајамна искључивост модерне индивидуалности и аскетског духа хришћанства, која се тек накнадно испољила и као културолошка различитост, говори нам и пример грчког писца Никоса Казантзакиса (1883-1957), који је, иако одгојен у традиционалном православном духу, водио искрену и тешку борбу модерног човека ка обожењу. Насупрот Ендоу, који је рано осетио отпор према строгом католицизму као нечему туђем, Казантзакис још у својој раној детињој уобразиљи активно тежи све-

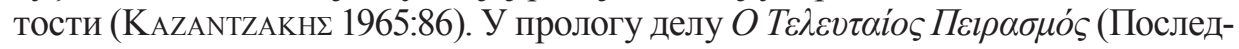
ње искушење, 1950/51), писац исповеда своје убеђење да је обожење, као сједињење с Богом, једини човеков задатак. Истовремено, међутим, открива и истину о „непрестаној и немилосрдној борби између духа и тела.“ Ова борба, универзална и древна хришћанска тема, битка је земаљског човека

с хришћанством, попримити веће и озбиљније димензије. Остао је, међутим, упамћен и као особа широког и отвореног духа, о чему сведоче и његови хумористички есеји.

11 О неодвојивости мајчиног лика и духовности код Ендоа сведочи и сведочанство пишчеве супруге Ђунко. Када је Ендо децембра 1996. године преминуо у болници, Ђунко je, како сама каже, посредством додира њихових руку примила поруку свога супруга да се налази у светлости и да се сусрео с мајком и братом. Како је претходно објаснила, последње три године живота Ендо је провео у болници а годину дана пред смрт изгубио је способност говора. Због тога, њихова комуникација одвијала се непосредним физичким додиром руке, у потпуној тишини. 
за свој метафизички смисао између материје и духа. Тек с временом, она поприма интелектуалну комплексност и обележја сукоба између тешко измирљивих идеја и концепата које модерна индивидуа преузима на своме путу између земље и вечности.

Поље укрштања тежњи духа са захтевима тела - допустимо овде такав дуализам - примарно је место стицања и осведочења вере, док су философски концепти апстраховани одрази и накнадна промишљања таквог односа према своме смислу и траг који човек оставља на том путу. Од домашаја тих интелектуалних концепата, који ипак остају у власништву мањине, далеко је већа снага културних образаца у видовима исповедања и упражњавања вере, који неретко остају непрепознати иако учествују у сваком доживљају трансценденције, представљајући не само форму веровања, већ и његову садржину. Непознато нам је, наиме, било какво сведочанство о доживљају више стварности које већ у својој основи не би било артикулисано дубоко усађеним претпоставкама одређеног учења унутар којега се то искуство препознаје и признаје. ${ }^{12}$ Примарна дуалистичка борба тела и духа код обојице писаца попримила је ток побуне не, наизглед, против вере у Бога, већ против традицијом задатих њених оквира, дакле управо оних непопустљивих форми кроз које се она испољава. За Казантзакиса, традиција се јавља као простодушна вера православног Крита с коренима, како каже писац, дубоко у земљи и високо на небу, а код јапанског писца она се задаје у виду накнадно стечене мајчине католичке вере, али без икаквих дубљих домаћих корена. У Ендоовом случају, неки аутори говоре о унутарњем метафизичком повратку (HagiwARA 2000) Јапану с католичког Запада, док је Казантзакис захтевао усклађивање хришћанства с научним спознајама XX века (BIEN 2009). Но, док је Крићанин очувао своју рану представу о светитељу као хероју, ${ }^{13}$ те ће тако и човек постати ништа мање до саборац Бога, Ендо је „ослабио“ тврдоћу хришћанског призива и увео свепраштајући, али тужни и пасивни лик Христа као сапутника слабих. За грчког писца, човек спасава чак и Бога, бијући свекосмичку битку за „пресуштављење“ материје у дух. Човек је за њега онај који, будући земаљски прах, чак и такав у својој ефемерности чува вечност божанског даха. Казантзакис се, извесно је, у својим интелектуалним визијама, између осталога, надахњује либералном теологијом тога времена, која је Божанској личности одрицала апсолутну непромењивост и унутрашњу затвореност у теолошки конструисаној самодовољности (BIEN 2009). Ендоов бог̄, с друге стране, не усклађује се с науком већ

12 О могућности тзв. чистог искуства трансценденције говори се често у контексту зен-будизма, чији су проповедници за Западу управо у зену видели могућност религије ослобођене свих културно-историјских условљености. Много се тога, међутим, може приговорити тези о таквој универзалности зена, што се, уосталом, често и дешавало на пољу студија зен-будизма последњих деценија.

${ }^{13}$ Као дете, он је веровао да је његов деда, који је својевремено војевао против Турака, заправо био светитељ. 
постаје божанство слабих, које не грца у епској бици за свеопште спасење и обожење, већ својим духом љубави милује и умирује сваког палог и немоћног појединца.

О духовном усмерењу и једног и другог писца довољно казују речи које су, по њиховом избору, остале забележене на споменицима. На Казантзакисовом гробу урезане су следеће речи, чије се порекло приписује стоичком философу Димонаксу (II век): „Не надам се ничему, не бојим се ничега - ја сам слободан.“"Насупрот овоме борбеном и изазивачком узвику Казантзакисовом, стоји сетно зачуђена и резигнирана у немоћи Ендоова мисао коју је наменио камену споменику постављеном у Нагасакију, на једном од местаิ за која се везују радња романа Ћуйање и повест страдања хришћана. На узвишењу с погледом на море, за које је сам писац приметио „да га је сам Господ за њега припремио“, стоји Споменик ћутања (沈黙の碑/Chinmoku no hi), на којему су уклесане ове Ендоове речи: „Како је човек жалостан, о Господе, а море је тако плаво“. Ове тихе речи одјекују за многе хришћане претешким питањем Божјег ћутања и остају зачуђене пред противречношћу између лепоте његове творевине и узалудности људског страдања. То нас доводи до проблема теодикеје и смисла страдања у свету, те односа Бога према људској судбини, што су важне теме овог дела. Реч је, дакако, о тајни Божјег промисла и суморне слике онога што се човеку тако често чини као равнодушност, или још горе од тога - као необјашњиво и злокобно одсуство Створитељево из сопствене креације. Управо је ово средишња тема романа Ћуйање.

Уколико процес рецепције хришћанства код Ендоа поделимо на три развојне етапе, ${ }^{14}$ онда би ово дело представљало врхунац друге фазе, која траје од 1966. до 1980. године. Ендо током овог периода долази до визије Христа која је, закључићемо, више лични и компромисни модус прихватања неприхватљивога но што је доиста израз некакве јединствене традиционалне антропологије. Његов Христос попут самилосне мајке, а писац управо тако замишља и апсолутни алтруизам будаิ, сам ће нечујним гласом охрабрити португалског свештеника да пред јапанским мучитељима ногом стане на његов изображени лик, да порекне своју веру и тако смрти спасе групу јапанских хришћана. За Ендоа, инкултурација се није састојала у укључивању домаћих елемената у католички обред, већ у промишљању питања тога шта значи бити хришћанин тамо где се традиционални ауторитети Цркве не подразумевају а конвенционално веровање није делатно. Далеко од тоталитета историјске хришћанске свести Запада, божанска моћ је у Јапану релативизована и до свог ауторитета мора доћи показивањем не надмоћне, већ хуманизоване љубави и снисхођења према човеку у његовој слабости.

Неминовно је било, како за Ендоа и Казантзакиса, тако и за друге - Берђајева, Достојевског, као и свакога ко жели да проникне у значење људске

${ }^{14}$ Масе-Хасегава тај процес код Ендоа посматра дијалектички, на начин да прву фазу (1947-1966) карактерише пишчев антагонизам према хришћанству, другу (1966-1980) измирење у разумевању, док се у трећој (1980-1996) остварује синтеза супротности. 
патње у Божанској икономији људског спасења - поћи од личности самог Христа, који и сам изговара најзагонетније речи Новога завета: „Боже мој, Боже мој, зашто си ме оставио?“ (Мт. 27, 46) Вероватно је и заједничка проблематика особених „христологија“ код јапанског и грчког писца, које свака на свој начин представљају ослабљену и хуманизовану личност Христа, навео редитеља Мартина Скорсезеа да баш према њиховим романима сними филмове Последње Хрисиоово искущење (1988) односно Тищина (2016)..$^{15}$

Као што је познато, роман се темељи на низу историјских догађаја који су водили гушењу хришћанске вере и католичког мисионарског деловања у Јапану током XVII века. Године 1597. погубљено је двадесет и шест мученика у Нагасакију а европске католичке кругове нарочито је погодила вест о томе да се језуита Кристовао Фереира 1633. године у Јапану, после тешких мучења, одрекао хришћанства и остао да живи у тој земљи као натурализовани Јапанац, под новим именом Савано Ћуан. Било је, изгледа, оних који су се потом и сами упутили у Јапан, било да мученичком смрћу искупе Фереирин грех, било зато да се увере у истинитост гласина и, евентуално, одбране угледног језуиту. Прича о Фереири, колико нам је познато, никад није добила свој званични епилог, иако постоје сведочанства о томе да је он пре смрти опет јавно исповедио своју веру и - мученички пострадао.

Роман обрађује тему унутарње борбе и, на крају, апостасије једног од двојице младих свештеника који кришом одлазе у Јапан да би утврдили шта се заиста десило с њиховим некадашњим учитељем. Један од њих, Франциско Гарупе, и сам гине приликом покушаја да одбрани неколицину из своје јапанске пастве, док Себастиао Родригез допада много трагичније судбине: бира други, компромисни, начин да од мучења избави групу јапанских верника и у симболичном чину одрицања од вере ступа ногом на Христову икону ( fumie). То је највиша тачка фабуле овог романа а овакав исход Родригезове драме суптилно али непогрешиво наговештавала је већ психолошка мотивација јунака у његовим дотадашњим искушењима. Одрицању ради спасавања не свога већ живота других морао је претходити напад духа сумње, који Родригеза обузима на врхунцу бесциљног лутања и скривања по беспућима, након што су двојица најпожртвованијих и у вери најутврђенијих хришћана села Томоги, Ићизо и Мокићи, спором смрћу погубљени на обали мора.

Одлазећи мученички, али не на свечан начин описиван у житијима већ „бедном“ и анонимном смрћу, они остављају мисионаре без заштите у селу

${ }^{15}$ Назив дела у преводу на српски језик гласи Ћуш̄ање, што је и најближни превод јапанске речи „ћинмоку“. Истоимени филм је, са друге стране, на српскоме понео назив Тищина, што се намеће као први превод речи „,silence“, како наслов филма гласи у оригиналу. Чини се да у енглеском језику недостаје именица која би недвосмислено изразила разлику између ћутања као одсуства гласа особе и тишине као одсуства било каквог звука. Тема романа је, међутим, недвосмислено управо „ћутање“ Бога, као одсуство његовог јасног одговора на јасно и болно исказане људске патње. 
и односе са собом део вере, каква је она до тада била, оца Родригеза. Након бесмисленог страдања добрих верника, у Родригезовој свести сусрећу се више пута Бог и море, обоје подједнако ћутљиви и равнодушни, што је исказано и у већ поменутим речима са споменика у Нагасакију. Мукло је, попут бубња у мрклој ноћи, одјекивао бесмислени шум таласа, који су се кретали без икакве сврхе и равнодушно омивали мртва тела двојице мученика. После њихове смрти море је остало непромењеног „израза лица“, простирући се у упорном ћутању о ономе што је видело - баш као и Бог. Најстрашније Родригезово искушење прате и најзлокобније помисли: „То је немогуће, помислио је и одмахнуо главом. Када Бога не би било, човек не би могао да поднесе ову једноличност мора и његову злокобну равнодушност. (Међутим, у случају да - наравно, само у случају да је тако...) Негде дубоко у његовим грудима један други глас је у том тренутку прошапутао. (У случају да Бога ипак нема...).“ (遠藤 1993:301) Ово страшно и неподношљиво питање не доводи Родригеза до метафизичког очајања - у њему оно буди осећање апсурдности и комичности живота свих оних који су за веру пострадали.

Берђајев је написао да је узрок атеизма код руских интелектуалаца XIX века био етичке природе, тј. изазван немогућношћу да се реши проблем теодикеје и оправда постојање патње (BERDYAEV 1948:78-79). Прототип такве модерне индивидуе, сувише трагичан и сувише идеалиста да би веровао у то да се светска хармонија остварује патњом невиних, био је Иван Карамазов. Но, вероватно не би исправно било закључити да у лику свога јунака Ендо непосредно исказује властите сумње. Његова вера је, по свој прилици, доиста морала бити озбиљно испитивана, јер без тога не би било ни његове књижевности, што се може казати и за Достојевског. Верујемо, ипак, да разлог трајне свежине и актуелности Ендоовог књижевног дела лежи управо у томе што се он, као писац, не поверава у потпуности својим јунацима, нити се, пак, од њих отуђује остављајући их у области чисте фикције. Писац остаје на граници свог књижевног света, у сталном дијалогу с ликовима које сасвим очигледно „одушевљује“, задржавајући право на то да као спољашња инстанца у односу на њихов свет сачува комплексност каква је књижевном јунаку немогућа.

Ендо ће, дакле, Родригеза предати снажној скепси, какву је можда и сам искусио, а онда га оставити да сам испуни своју судбину и проживи своје искушење до крајњих последица. Злобни глас демона сумње долази да мучи човека модерног доба - а свештеник у овом роману несумњиво је човек модерне свести иако је време радње у далекој прошлости - у лику његовог властитог разума, што је у роману опет тужна повластица човека Запада. Запитаност над могућношћу и оправданошћу вере уопште, сазревала је у писцу од раног узраста, али он се у својој књижевности не суочава с тим питањем непосредно и у његовој универзалности, већ од у жижу свог интересовања ставља проблем хришћанске вере на нехришћанском тлу. Засићен и разочаран ,западњачким“ хришћанством у Француској и свестан тога да, 
као Јапанац, не може бити ни прихваћен нити хомогеенизован унутар те културе, он неминовно проблематизује оно што сматра културолошком димензијом хришћанства, не усуђујући се ипак да га и одбаци. Уместо тога, бира пут релативизације онога што сматра спољашњим слојем вере - тј. религију - и утврђује се у убеђењу да ,јапанско хришћанство“ мора бити другачије.

Неспособност јапанског духа да искрено прихвати страну религију каква је хришћанство, Ендо објашњава следећим трима одликама, за које налази да су том духу инхерентне: неосетљивост према Богу; неосетљивост према греху; неосетљивост према смрти. Човек Запада, написаће у једном од својих дела, није у стању да порекне постојање трансцендентног Бога, чак и када то наизглед чини. Нешто слично доиста можемо видети и у лику Ивана Карамазова (који у Бога не верује, али га поштује!). Насупрот томе, јапанска религиозна свест на такву апсолутну инстанцу не рачуна - њен доживљај света је пантеистички а спасење не долази „свише“, већ се остварује у хоризонталној и слојевитој интеракцији са свим бићима. Ипак, као књижевник Ендо је, делећи сферу духовног искуства на два табора, тј. Исток и Запад, превидео извесност онога што смо претпоставили већ на почетку: хришћанство је данас подједнако страно и Истоку и Западу а сваки његов сусрет с индивидуалном душом већ је инкултурација - па чак и трансформација - чије су импликације далекосежне и другима непознате.

Од савремених православних духовника можемо чути то да је душа по својој природи хришћанка, док својим страстима, дакле у свакодневној реалности, остаје паганка. Међу мислиоцима, још је смелији, на пример, Василије Розанов, који је у себи отворено и свесно гајио противречности као што су византијски монашки пијетизам, с једне стране, и вишебожачки паганизам с афирмацијом сексуалности. Следећи свој програм инкултурације, Ендо занемарује чињеницу да ни особа која хришћанско учење баштини вековима не борави постојано у монолитности свог верског идентитета, већ остаје у агонији између два бездана, једног божанског и другога који је, ништа мањом снагом, вуче у ништавило без Бога. Чини се да је он, разочаран оним што је од хришћанства видео у Француској и убеђен у непремостивост јаза међу културама, хришћанство Запада препустио лаганом пропадању, да би на Истоку пронашао један његов виталнији и „природнији“ вид.

Падре Родригез, делом и пишчев алтер его, током свог скривања у планинама све више бива дисоциран од своје вере а властито унутарње стање проверава у одразу свога лица, огледајући се у води на коју повремено наилази. Оно је час Христово лице, час се показује искривљено у комичну гримасу. Као значењем посебно обремењен модалитет воде, Ендо учестало користи и мотив „мочваре“, метафоре за преображавајућу силу, хтонског призвука, која делује у дубинама јапанске културе и у животу оставља само оно суштину чега успе потпуно да измени. Када се Родригез најзад буде сусрео с Фереиром, овај ће му објаснити да се Јапанци никад нису ни молили уистину хришћанскоме Богу. У Јапану, каже он, Бог доживљава судбину лептира ухваћеног у паукову мрежу: споља, он је и даље исто божанство; 
но, оно што опстаје заправо је само празна љуштура, док је суштина непрепознатљиво измењена. Судећи по претходно наведеним Ућимуриним речима, у овоме је Фереира, а с њиме и Ендо, вероватно у праву. Но, нису силе некакве чисте аутохтоне културе оно што растаче ткиво свега придошлога. Сама та наводно домаћа матрица већ је по своме постанку и деловању хетерогена и изразито плурална у синкретизму домаћег и страног, те било каква ,јака онтологија“ с вером у изоловану и искључиву трансценденцију унутар ње није могућа.

Ендо се одриче хришћанства догмата и одступа од предања, што ипак није могао да учини и, будући свештеник, његов пријатељ Иноуе. ${ }^{16}$ Ни Родригез, као пишчев алтер его, у своме искушењу не прибегава, стога, традиционално монашким начинима разумевања и превазилажења свога стања, добро познатог у аскетској литератури. Не знамо колико је писцу био познат појам „богоостављености“, о чему бар од времена Антонија Великог до наших дана сведочи искуство духовног живота. О њему је писао Исак Сирин, за њега су знали и савремени подвижници као што је Силуан Атонски, а у наше време о томе веома упечатљиво и необично отворено казује и митрополит Николај Хаџиниколау. У Католичкој цркви оно се описује као тамна ноћ душе, а било је познато и Терези од Лизјеа. Како каже Иларион Алфејев, тумачећи дело Исака Сирина, богоостављеност има само два могућа исхода: налажење или губљење Бога.

Ендоов јунак је већ неповратно „осавремењен“, готово постмодеран човек и поборник „слабе вере“: он не оцењује вредност жртве ( $\theta v \sigma i ́ \alpha)$ у односу на вечни живот, већ у онима којима је спремљен венац мучеништва види тек жртве ( $\theta \tilde{v} \mu \alpha)$ космичке неправде и „великих прича“. Он није аскета, већ хуманиста савременог доба. Иако свестан крајње беде у којој његова јапанска паства проводи своје кратке овоземаљске дане, свештеник чини нешто незамисливо: избавља их управо за овај живот, лишавајући их награде на небесима. Он овде не размишља о есхатону - прибегава не логици мученика, већ бодхисайве, будистичког светитеља који приноси највећу личну жртву спасавајући друге у нужди. И код Казантзакиса се последње Христово искушење састојало у могућности избављења од крсне смрти, да би потом проживео - на то га наводи кушач - безбрижно у благодетима овога света. Ипак, он на крају побеђује демонско искушење и страда, на начин који је Ендоовом јунаку био немогућ. Већ је примећена сродност Ендоовог

${ }^{16}$ Иноуе такође примећује да хришћанство у Јапану носи лице Христа какво је било обликовано и представљено на Западу, због чега је у Јапану неопходно наћи Спаситељев другачији лик, који би се присније коснуо душа самих Јапанаца. Но, будући ипак свештенослужитељ, он се није одважио на испитивање могућности непостојања Бога. Своје узоре смиривања пред тим страшним питањем налазио је у крилу Цркве, и Истока и Запада. Нарочиту приврженост показао је према личности Терезе од Лизјеа, кармелићанске монахиње познате по своме „малом путу“, као практичној вери свих оних који су, као мали и немоћни, упућени на ситна добра простосрдачне љубави у свим животним околностима. 
хришћанства јапанскоме будизму Чисте земље, који обећава спасење свакоме грешнику, без обзира на уложени труд, обрати ли се он само буди Амиди (MASe-Hasegawa 2008:131). Становиште тог својеврсног етичког монизма, карактеристично за источњаки начин превазилажења дуалности, видљиво је и у последњем Ендоовом роману Дубока река (深い河/ Fukai kawa, 1993), који се сматра круном коначног, трећег стадијума пишчеве трансформације хришћанства. ${ }^{17}$

У Ћуйању, пак, Родригез и после одрицања себе сматра свештеником, верујући да је у ћутању Бога заправо чуо Христов глас, који га је у критичном тренутку охрабрио на тај, сваком хришћанину незамисливи, чин. Христос му се тихо јавља и, попут мајке, дошаптава да слободно згази његов лик, јер је он на земљу и дошао да би био згажен и презрен, као онај који ће са слабима састрадавати занавек. Овом свештенику „слабе вере“ на крају, док у Јапану наставља свој противречни живот слободног заточеника, остаје само један од његове пастве: онај који га је, као Јуда, изручио гонитељима. То је Кићиђиро, јапански хришћанин који је много пута падао и враћао се вери кроз исповест, само да би изнова починио издајство. Родригез с потиснутим гађењем гледа на тог, у својој крајњој беди и бескарактерности, најнижег од свих људи, не примећујући да и њега самога јапанска мочвара раслабљује и лишава пређашње одлучности.

Ендо не идеализује Кићиђироа, кога беспоштедно описује у пуноћи његове физичке и духовне беде, без видљивих знакова симпатије. Све нам јасније бива и то да је овај отпадник такође пишчев алтер-его, што се недвосмислено потврђује онда када се Ендо у једном другом тексту поистовећује с тзв. скривеним хришћанима из прошлости своје земље, који су живели у срамоти одступништва и чије је хришћанство постепено попримило веровања и обредне форме сасвим отуђене од првобитних. У лику Кићиђироа рехабилитован је чак и сам Јуда, сличност којему се недвосмислено наглашава, а највише у његовом чину изручивања Родригеза властима за двеста сребрењака. Ендо тако у крило хришћанства враћа непризнати род „тајних хришћана“" уопште, ${ }^{18}$ почев од Јуде, и свих оних за које у синаксарима и мартирологијима нема места - све до њега самога, као потомка својих слабих и за мучеништво неспособних предака.

17 Савремено гледиште о аутономији дела у односу на аутора тешко ће објаснити чињеницу да је Ендо, на сопствени захтев, сахрањен с примерцима својих романа Ћуйање и Дубока река.

18 Као што је познато, у историји Цркве многи њени чланови живели су као тајни хришћани, но само уколико нису били препознати и позвани да се јавно изјасне. У том случају, хришћанин је дужан да своју веру јавно исповеди, без обзира на последице, следујући тако Архимученику, самоме Христу. Ендо „легитимизује“ ону другу, непризнату линију, која потиче од занавек проклетог Јуде, али чију реалност својим одрицањем наговештава и сам апостол Петар. Ова новозаветна сцена призива се недвосмислено и у роману: у тренутку када је Родригез стопалом додирнуо Христов лик на икони, зачуло се како певају први петлови. 
На последњих неколико страница романа Родригез, кога у оближњем Нагасакију народ већ зове „пали Павле“19 и који ће на крају чак добити јапанско име Окада Сан'емон, по први пут „са слободе“ посматра свакодневни живот обичних Јапанаца, у обичним и искреним манифестацијама религиозности понегде толико сличан његовом родном Португалу. У тим тренуцима, узгред примећује да ни између њега и Кићиђироа стварне разлике можда и нема, што је читаоцу наговештај да следи моменат њиховог поновног сусрета, првог после издаје, када тај недостојни хришћанин долази овом вероватно већ рашчињеном свештенику на исповест. Убеђен у то да је могуће издати земаљску јерархију остајући и даље у небеској, Родригез самоме себи потврђује своју оданост Христу, који ипак није ћутао у одсудном часу - а ако и јесте ћутао, онда је он, Родригез, о њему говорио и сведочио целим својим дотадашњим животом. То му даје смелост да, будући последњи свештеник у Јапану, прочита на крају Кићиђироу разрешну молитву.

Настао на традицији јапанске прозне фикције с израженом тежњом да се документује унутарње субјективно искуство, роман Ћуйање најпознатије је Ендоово дело у дугачком низу његових литерарних настојања да измири свој јапански сензибилитет са строгим догматским захтевима хришћанске вере. Сви покушаји да католичанство одбаци као туђе, били су, по пишчевим речима, безуспешни јер је оно већ постало саставни део његове личности, онај Други који нас изнутра отуђује од нас самих, позивајући рањиво и никад до краја формирано сопство да иступи и идентификује се. Приповест у својој основној идеји заснована на сукобу двају метафизичких и онтолошких модела, теоцентричнога западњачког што афирмише трансцендентно Једно и децентрализованог источњачкога, који унутар хоризонталне антропоцентричне равни тежи инклузивности и иманенцији, разоткрива се при крају као универзална прича о унутарњој молитви и о човековом односу с личносним Богом као доживотној дијалектици вере и сумње. Иако Ендоова теологија и његово решење главних недоумица верујућег човека модерног доба, као ни у случају Казантзакиса деценијама пре тога, нису наишли на одобравање католичких критичара, ${ }^{20}$ не може се порећи универзални значај његовог дела, као ни пишчево право да се, као и Достојевски много пре тога, у литерарној форми обрати оним питањима која теологија углавном заобилази.

Вероватно је Ендо у својој интерпретацији, тежећи да се ослободи тврдих и обавезујућих догмата у страном руху, склизнуо у личну и произвољну догму друге врсте, у крајњој линији ипак немоћну да савременом човеку помогне у проналажењу делатног личног модуса инкултурације хришћанства на мочварном тлу сопственог живота. У жељи да „туђе“ парадигме

19 Павле је било и Ендоово хришћанско име.

20 Папа Павле VI је, недуго по објављивању романа, у обраћању верницима у Нагасакију препоручио да га не читају. 
преведе на културолошки прихватљиве алтернативе, писац је, можда, изгубио из вида стварну сложеност питања којима се, несумњиво на пажње вредан начин, бавио. Његов последњи роман Дубока река, подједнако значајан колико и Ћуйање, одлази даље у правцу источњачког пантеизма, а спаситељска и искупитељска личност Христа релативизује се још више. Христос губи своју историјску конкретност, име и лични карактер, и бива протумачен као безимено инкарнирано начело љубави у плуралистичком свету. Чини се да је јапанском писцу непозната она „заљубљеност“ која је навела Достојевског да каже како би радије изабрао Христа него иситину, уколико би се то двоје нашло у односу међусобне искључивости. Но, Ендоово дело, с друге стране, подсећа нас на то да је искуство Бога у данашње време неминовно и плуралистичко и лично, те на то да се до њега мора доћи - оно није наследно и дато традицијом.

Колико год да се Ендо, у својој списатељској креативности, удаљио од богословских аксиома, што се може сматрати и неопходношћу без које би приповедачев глас вероватно утихнуо и никаквог разговора више не би ни могло бити, може се претпоставити да је он, у основи, на свој начин следио ону визију хришћанина коју и Павле Евдокимов исказује следећим речима: „Хришћанин је јадан човек, али он зна да постоји Неко још јаднији, а то је онај Просјак љубави на вратима нашега срца““(Евдокимов 2001: 21).

\section{ЦИТИРАНА ЛИТЕРАТУРА}

Berdyaev, Nicolas. The Russian Idea. New York: The Macmillan Company, 1948.

Bien, Peter. The Philosophical Basis of Kazantzakis's Writings. <https://www.onassis.org/ enim_deltio/foreign/14/peter_pien_speech.pdf $>10.01 .2019$.

遠藤, 周作. 沈黙. 遠藤周作集. 新潮日本文学56. 東京: 新潮社1993年.

Евдокимов, Павле. ,,Луда“ љљубав Божија. Хиландарски преводи. Света Гора Атонска: Манастир Хиландар, 2001.

Hagiwara, Takao. Return to Japan: the Case of Endô Shûsaku. Comparative Literature Studies, 37/2 (2000): 125-154.

伊藤, 聡. 神道とは何か 神と仏の日本史. 東京:中央公論, 2014.

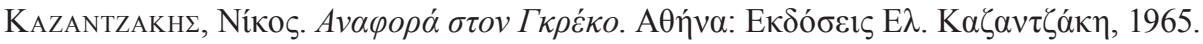
金子, 盾夫. 井上洋治師と遠藤周作の「日本人のキリス卜教」を求めて内開花 文化的受肉の

観点からー」.<http://www.jacp.org/wpcontent/uploads/2016/03/2009_36_hikaku_11_ kaneko.pdf $>$ 08. 01. 2019.

Kazuyoshi, Terao. A Catholic attempt at Naikan meditation. Religion and Psychotherapy in Modern Japan. Christopher Harding, Iwata Fumiaki, Yoshinaga Shin'ichi (ed.). London - New York: Routledge, 2015.

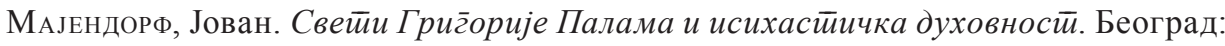

Задужбина Светог манастира Хиландара, 2012. 
Mase-Hasegawa, Emi. Christ in Japanese Culture: Theological Themes in Shusaku Endo's Literary Works. Brill's Japanese Studies Library 28. Leiden - Boston: Brill, 2008.

Muluins, Mark R. Christianity made in Japan: A Study of Indigenous Movements. Honolulu: University of Hawa'i Press, 1998.

САХАРов, Софроније. О молит̄ви: збирка чланака. Хиландарски преводи. Света Гора Атонска: Манастир Хиландар, 2009.

Shields, Mark, J. Smashing the mirror of Yamato: Sakaguchi Ango, Decadence and a (Post-metaphysical) Buddhist Critique of Culture. Japan review: Journal of the International Research Center for Japanese Studies 23. Kyoto: International Research Center for Japanese Studies, 2011, 225-246.

Sueki, Fumihiko. Istorija japanske religije. Beograd: Albatros Plus, 2016.

Swyngedouw, Jan. Secularization in a Japanese Context. Japanese Journal of Religious

Studies 3/4. Nagoya: Nanzan Institute for Religion and Culture, 1976, 283-306.

Williams, Mark B. Endo Shusaku: A literature of reconciliation, London - New York: Routledge, 1999.

Dalibor D. Kličković

\author{
INCULTURATION OR TRANSFORMATION: CHRISTIANITY \\ IN THE NOVEL SILENCE BY THE JAPANESE WRITER \\ ENDO SHUSAKU
}

Sum mary

Endo Shusaku had always been recognized as the greatest "Catholic writer" in Japan, even dubbed as Japanese Graham Greene. Indeed, by far the biggest part of his opulent literary work is obviously dedicated to the very question of how to cope with his own catholic faith. He had been thinking of Christianity as being essentially at odds with his Japanese making ever since he received it as a boy, by his mother's will. This insight was going to inspire his endeavors to recast the Christianity so as to come to a different understanding of it, that would be acceptable for the Japanese and, at a later stage, for all non-Europeans. In his novel Silence, such a Christianity is conceived of as being based on an image of the suffering Christ, a Christ not so much the redeemer as a fellow traveler through the sufferings of the weak ones. Thus imagined, Christ seems to be made feeble and deprived of his divine prerogatives to fit a rather anthropocentric perspective, with his metaphysical meanings in a traditional sense reduced to almost nothing. Such a version of Christianity forged by Endo resembles more modern discourses of the Japanese Buddhism than the sturdily articulated dogmata and strictly observed set of creeds, mandatory for every Catholic. Willing to create an oriental Christianity, Endo humanized it, much in the manner of the liberal theology eager to be inclusive and tolerant of almost any form of faith, as long as it is professing love. The weak theology of Endo is well-suited as a literary model of human dialogue with God, in a work of fiction. 
However, as a mode of human relationship to the divine transcendence, which we believe actually was the principal goal of Endo's thought, it is reduced to the "weak faith", that is not obligatory anymore for either side related, neither Christ nor man.

Универзитет у Београду

Филолошки факултет

Студентски трг 3, 11000 Београд

daliborklickovic74@gmail.com 